\title{
Prevalence and incidence of disability based on the Unique Certificate of Disability at a teaching hospital in the Metropolitan Area of Buenos Aires
}

Celeste Puga, M.D. ${ }^{a}$, Vanina Pagotto, M.D. ${ }^{b}$, Diego Giunta, M.D. ${ }^{b}$, Jimena Vicens, M.D. ${ }^{b}$, Mariana Leist, M.D. ${ }^{a}$, Esteban Vaucheret Paz, M.D. ${ }^{a}$, Lucila Hornstein, M.D. ${ }^{c}$, Leonardo Garfi, M.D. ${ }^{c}$ and Guillermo Agosta, M.D. ${ }^{a}$

\begin{abstract}
Disability is a public health problem that affects an individual's comprehensive developmentopportunities. The objective of this study was to estimate the annual incidence and prevalence and the diagnostic categories associated with total disability and age groups based on the application for a Unique Certificate of Disability.

This was an analytical cohort study in children aged 0-18 years conducted at a teaching hospital of the Metropolitan Area of Buenos Aires between January 2010 and December 2017. Among 22750 active members, 726 patients applied for a Unique Certificate of Disability; the prevalence was $3.2 \%$ (95\% confidence interval [CI]: 2.9-3.4). The annual cumulative incidence increased from $2012(0.22 \%, 95 \%$ CI: 0.1-0.19) to 2017 (0.59 \%, 95 \% CI: 0.5-0.7). Mental disabilities accounted for $80 \%(\mathrm{n}=576)$.

This study showed an increase in the incidence of disability and also the mental disability category.

Key words: people with disability, epidemiology, autism spectrum disorder, intellectual disability, pediatrics.
\end{abstract}

http: / / dx.doi.org/ 10.5546/ aap.2019.eng.183

To cite: Puga C, Pagotto V, Giunta D, Vicens J, et al. Prevalence and incidence of disability based on the Unique Certificate of Disability at a teaching hospital in the Metropolitan Area of Buenos Aires. Arch Argent Pediatr 2019;117(3):183-187. a. Department of Pediatrics, Division of Neurology of Hospital Italiano de Buenos Aires.

b. Department of Research, Hospital Italiano de Buenos Aires.

c. Management of Hospital Italiano de Buenos Aires Health Plan.

E-mail address:

Celeste Puga, M.D.: celeste.puga@hospitalitaliano.org.ar

Funding: None.

Conflict of interest: None.

Received: 6-12-2018

Accepted: 12-5-2018

\section{INTRODUCTION}

According to the World report on disability, 95 million children worldwide have a disability, of which 13 million $\left(0.7 \%\right.$ ) have severe disability. ${ }^{1}$ In Argentina, the 2003 National Survey of People with Disability (Encuesta Nacional de Personas con Discapacidad, ENDI) estimated that $7 \%$ of inhabitants were living with a disability, of which 254497 were children younger than 15 years $(4 \%)^{2,3}$

The International Classification of Functioning, Disability and Health (ICF) defines disability as a generic term that encompasses deficiencies, activity limitations, and participation restrictions. ${ }^{4}$ Disability is understood as the interaction between an individual with a health condition (e.g., cerebral palsy, Down syndrome, and depression) and that individual's environmental and personal factors (e.g., negative attitudes, inaccessible transportation and public buildings, and limited social support).

Although studies on disability are based on the ICF's conceptual framework, there are differences in the data on prevalence, the type of questions asked, their order, and the sampling frame employed. ${ }^{1,5}$

In Argentina, people with disability may voluntarily apply for a Unique Certificate of Disability (UCD). ${ }^{6}$

The objective of this study was to estimate the annual incidence and prevalence and the diagnostic categories associated with total disability and age groups based on the application for a UCD and the request for supports.

\section{METHODS}

Design: Analytical, observational study conducted in a cohort of children aged 0-18 years based on electronic medical records of the Hospital Italiano de Buenos Aires Health Plan (HIBA-HP), between January 2010 and December 2017.

Population: Children with a UCD or disability with support needs, defined as therapeutic resources, assistive devices or strategies used 
so that people with disability develop their full potential in community settings. Patients were classified into four age groups: 0-4 years, 5-9 years, $10-14$ years, and 15-18 years.

Diagnoses were grouped into four categories, which were similar to those used in censuses and in the classification employed for UCD application, according to the Diagnostic and Statistical Manual of Mental Disorders, fourth edition (DSM-IV) and the International Classification of Diseases, $10^{\text {th }}$ Revision (ICD 10): mental disability (including children with autism spectrum disorder [ASD], intellectual disability, overall developmental delay, learning disorder, language disorder, and behavioral disorders), motor disability (cerebral palsy, neuromuscular disorders, neural tube defects), sensory disability (hearing impairment and blindness), and visceral disability (heart diseases, cystic fibrosis of the pancreas, short bowel syndrome).

\section{Statistical analysis}

The prevalence for the total period (2010-2017) and by age group was estimated using the annual weighted prevalence of active members younger than 18 years considering their age at the middle of the study period. The annual cumulative incidence of total disability and by age group was estimated considering the total number of active members younger than 18 years at the middle of the study period as denominator. Also, $95 \%$ confidence intervals (CI) were estimated for both incidence and prevalence. Continuous outcome measures were described as median and its corresponding 25-75\% interquartile range (IQR). Proportions were described as absolute and relative frequency. The protocol was approved by the Research Protocol Evaluation Committee of HIBA.

\section{RESULTS}

In the study period, among 22750 active members of the HIBA-HP, 726 patients younger than 18 years applied for the UCD or requested a therapeutic support, which resulted in a prevalence of $3.2 \%$ (95\% CI: 2.9-3.4\%) for the period. The median age of patients was 9 years (IQR: 5-12); $65 \%$ were males $(\mathrm{n}=478)$. In terms of age, $68 \%$ of patients $(n=496)$ were in the 5 -to14-year-old age group. Also, $91 \%(\mathrm{n}=662)$ had a UCD, whereas the remaining $9 \%(\mathrm{n}=64)$ had access to some sort of therapeutic support without

FIGURE 1. Overall annual cumulative incidence of disability per 100 members and $95 \%$ confidence interval

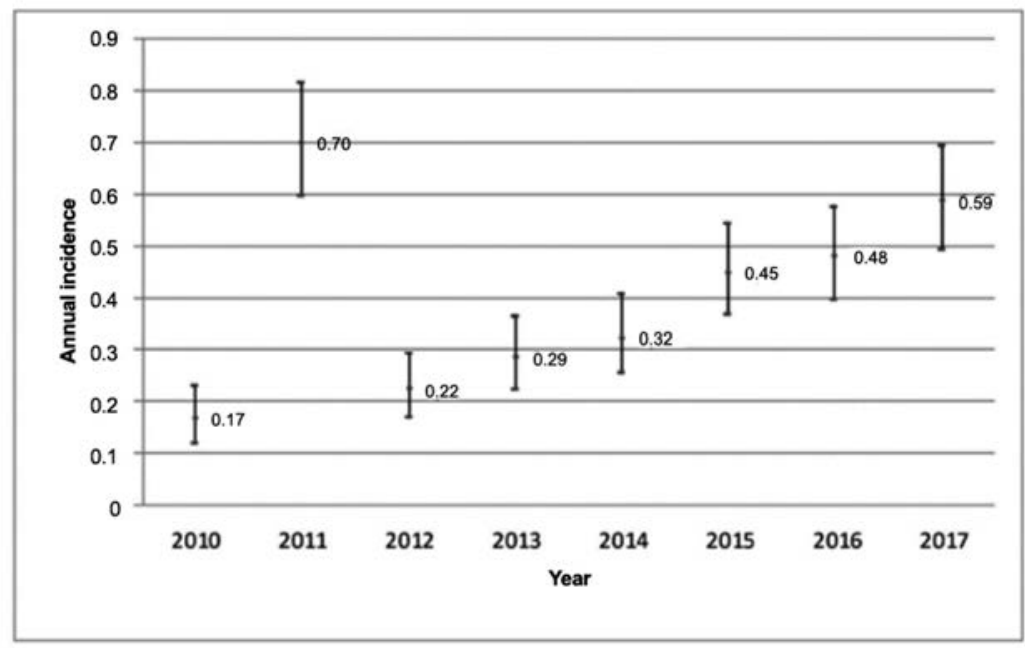

TABLE 1. Annual cumulative incidence of disability per age group every 100 members and $95 \%$ confidence interval

\begin{tabular}{lcccccccc}
\hline Age group & $\mathbf{2 0 1 0}$ & $\mathbf{2 0 1 1}$ & $\mathbf{2 0 1 2}$ & $\mathbf{2 0 1 3}$ & $\mathbf{2 0 1 4}$ & $\mathbf{2 0 1 5}$ & $\mathbf{2 0 1 6}$ & $\mathbf{2 0 1 7}$ \\
\hline 0-4 years old & 0 & 0 & 0 & $0.1(0.06-0.2)$ & $0.06(0.02-0.2)$ & $0.4(0.3-0.7)$ & $0.6(0.5-0.9)$ & $0.9(0.7-1.1)$ \\
5-9 years old & $0.09(0.04-0.2)$ & $0.3(0.2-0.5)$ & $0.4(0.2-0.5)$ & $0.4(0.28-0.6)$ & $0.6(0.5-0.9)$ & $0.5(0.4-0.8)$ & $0.6(0.5-0.9)$ & $0.9(0.7-1.1)$ \\
10-14 years old & $0.4(0.25-0.59)$ & $1.5(1.3-2)$ & $0.3(0.2-0.5)$ & $0.4(0.3-0.6)$ & $0.3(0.2-0.6)$ & $0.5(0.4-0.7)$ & $0.3(0.2-0.5)$ & $0.2(0.1-0.3)$ \\
15-18 years old & $0.3(0.17-0.58)$ & $1.5(1.14-2)$ & $0.2(0.1-0.5)$ & $0.08(0.03-0.2)$ & $0.1(0.06-0.34)$ & $0.1(0.04-0.3)$ & $0.1(0.07-0.3)$ & $0.2(0.1-0.5)$ \\
\hline
\end{tabular}


applying for such certificate.

In the 0-to-4-year-old age group, prevalence was $2 \%$ (95\% CI: 1.7-2.4\%); in the 5-to-9-year-old age group, $3.8 \%$ (95 \% CI: 3.4-4.3\%); in the 10-to14-year-old age group, $4 \%$ (95\% CI: 3.5-4.5\%); and, finally, in the 15-to-18-year-old age group, $2.8 \%$ (95\% CI: 2.3-3.4\%) for the period. Figure 1 shows the overall annual incidence and Table 1 describes the annual cumulative incidence and the incidence by age group.

In relation to diagnostic categories, $80 \%$ $(\mathrm{n}=576)$ of patients had mental disability. Among the remaining $20 \%$ of patients $(\mathrm{n}=150), 9 \%$ had a motor disability $(\mathrm{n}=64) ; 7 \%(\mathrm{n}=54)$, a sensory disability; and $5 \%$, a visceral disability $(\mathrm{n}=32)$. Also, $19 \%$ of patients had 2 or more disabilities (9\%, mental-motor disability; $6 \%$, mentalvisceral disability; and $1 \%$, mental-sensory disability). See Table 2. Among the 576 patients with a mental disability, $71 \%(\mathrm{n}=405)$ were males. Figure 2 shows the annual cumulative incidence of mental and non-mental disability in the study period. The proportion of patients with a mental disability diagnosis increased from $56 \%$ in 2010 to $88 \%$ in 2017, although no changes were observed in the population pyramid throughout the study period. The most common diagnoses among patients with mental disability were intellectual disability $(37 \%, \mathrm{n}=212)$, including Down syndrome $(18 \%, \mathrm{n}=38)$ and ASD $(40 \%$, $\mathrm{n}=234)$; these two accounted for $77 \%$ of all diagnoses in this category.

\section{DISCUSSION}

The prevalence of disability for the 20102017 period in the population of children who are members of the HIBA-HP was $3.2 \%$, which is lower than those reported by the $\mathrm{ENDI}^{2}(4 \%)$ and the 2010 Census $^{7}(4.8 \%)$, and closer to that reported by the Annual Household Survey (Encuesta Anual de Hogares, EAH), which showed a $3.1 \%$ prevalence in the same age group. ${ }^{8}$ It is difficult to compare the data from the ENDI, the 2010 Census and the EAH because, even though the surveys were designed according to the theoretical framework proposed by the ICF, information was collected in different manners. ${ }^{1}$

For this study, data used corresponded to records of requested supports, with or without a UCD. It was observed that most patients had

Table 2. Supplementary information of associated diagnosis

\begin{tabular}{lc}
\hline & $\mathbf{N}(\%)$ \\
\hline Mental disability & 576 \\
Autism spectrum disorder & $234(40)$ \\
Intellectual disability & 212 \\
$\quad$ Down syndrome & $38 / 212$ \\
Other genetic disorders (Prader-Willi, Sotos, Klinefelter) & $10 / 212$ \\
$\quad$ Epileptic encephalopathies & $3 / 212$ \\
$\quad$ Other diagnoses & $11 / 212$ \\
$\quad$ No etiologic diagnosis & $150 / 212$ \\
Language disorder & $39(7)$ \\
Learning disorder - ADHD - behavioral disorders & $77(13)$ \\
Other diagnoses & $14(3)$ \\
Motor disability & $64(8)$ \\
Cerebral palsy & $31 / 64$ \\
Myelomeningocele - spina bifida & $7 / 64$ \\
Neuropathy - myopathies & $9 / 64$ \\
Other (accidents - stroke - CNS tumors) & $17 / 64$ \\
Sensory disability & $54(7)$ \\
Hearing impairment & $52 / 54$ \\
Visceral disability & $32(4)$ \\
Heart diseases & $5 / 32$ \\
Cystic fibrosis & $5 / 32$ \\
Short bowel syndrome - ulcerative colitis - Crohn's disease - liver transplant & $9 / 32$ \\
Other & $13 / 32$ \\
\hline
\end{tabular}

ADHD: attention deficit hyperactivity disorder; CNS: central nervous system. 
a UCD. In Argentina, it is estimated that only $14.6 \%$ of people with disability have a UCD. ${ }^{9,10}$ Of these, $23 \%$ are children younger than 14 years, i.e., more than $70 \%$ of children with disability had not applied for a UCD. ${ }^{9}$ The difference in comparison with our study results may be due to multiple factors. In the study by Núñez et al., they mentioned that family members reported a lack of information in relation to legal affairs and basic rights, such as applying for a UCD or pensions. ${ }^{11}$ In order to apply for a UCD, it is necessary to consult a specialist in psychiatry or pediatric neurology, but this is hard to accomplish in some communities.

In relation to the cumulative incidence for each year of the study period, a marked increase was noted in 2011, which may be associated with the enactment of Act 26682 (Regulatory Framework for Private Health Insurance), which established that private insurance companies should provide coverage for, at least, what was established in the Mandatory Medical Program. .2,13 $^{2}$

In relation to the type of disability, the main diagnosis of most patients was mental disability. However, data published by the 2011 National Census reported that $35.1 \%$ had a visual limitation and only $26.3 \%$ had a cognitive limitation. ${ }^{14}$ Only in combination with other disabilities, cognitive deficit was more frequent. It is believed that such differences are related to the type of questions asked by the Census to characterize the different disabilities. ${ }^{14}$ The predominance of males diagnosed with mental disability was remarkably higher, which is consistent with other prevalence and incidence studies in developmental disorders. ${ }^{15}$
The analysis of annual incidence by diagnostic category showed that the incidence of sensory, motor, and visceral disabilities remained relatively unchanged throughout the 2010-2017 period. However, the mental disability category, which included intellectual disability, ASD, and behavioral disorder diagnoses, showed a sustained increase throughout the study period. Possibly, this is the result of a greater surveillance and knowledge among parents and physicians who perform health care for children. ${ }^{16}$

One of the limitations of this study is that the definition of disability was based on support needs (psychological, educational-psychological or physical therapy, school integration, orthoses or implants) with or without a UCD, so the total number of children with disability may have been underestimated because we did not include those who did not request support or did not have a UCD, even if they had a disability. Likewise, since this population of patients are members of a private health insurance plan and live mostly in the Metropolitan Area of Buenos Aires, results may differ from those in other regions of Argentina.

Disability is a public health problem that affects an individual's comprehensive development opportunities, making them vulnerable, especially due to the limited access to health and education. This study showed an increase in the incidence of disability together with an increase in the mental disability category. Having knowledge of prevalence and incidence data, as well as disability-associated diagnoses, is useful to develop care and intervention programs aimed at improving the quality of life and social inclusion of children with disability.

FIGURE 2. Annual cumulative incidence per 100 members by diagnostic category (mental or non-mental disability)

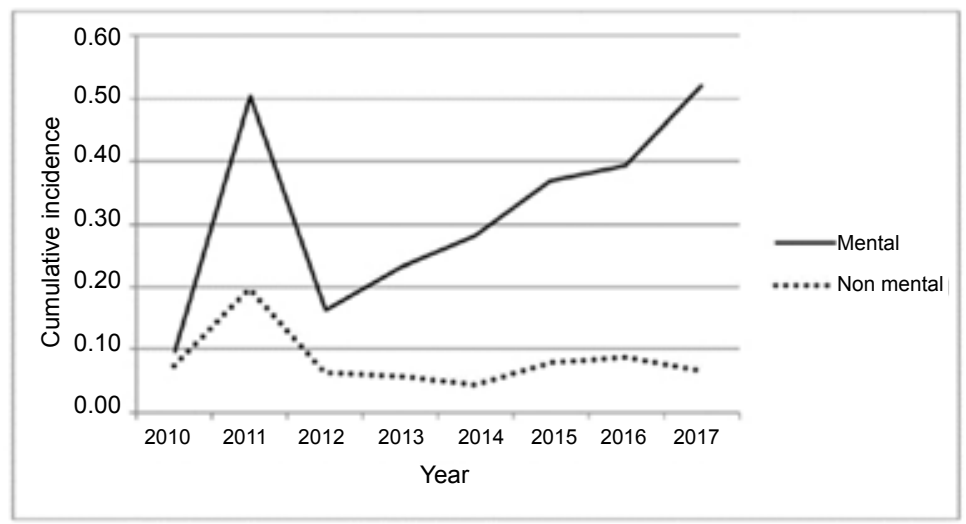




\section{REFERENCES}

1. Organización Mundial de la Salud. Informe Mundial Sobre la Discapacidad. Ginebra: OMS; 2011. [Accessed on: December $6^{\text {th }}$, 2018]. Available at: https: / / www.who.int / disabilities/world_report/2011/es/.

2. Rodríguez Gauna MC. Primera Encuesta Nacional de Personas con Discapacidad (ENDI) de Argentina. Su potencialidad para el estudio de la población con discapacidad. [Accessedon:December $6^{\text {th }}, 2018$ ]. Availableat: http:/ / repositoriocdpd.net:8080/handle/123456789/358.

3. INDEC Direcciones Provinciales de Estadísticas. Aquí se cuenta. Revista informativa del censo 2001 . 2004:14. [Accessed on: April 28 $\left.8^{\text {th }}, 2018\right]$. Available at: https: / / www.indec.gov. ar/micro_sitios/webcenso/aquisecuenta/aqui14.pdf.

4. Organización Mundial de la Salud. Clasificación internacional del funcionamiento de la discapacidad y dela salud:CIF:versiónabreviada.Madrid:Grafo;2001.[Accessed on:December $\left.6^{\text {th }}, 2018\right]$. Available at: http: / / apps.who.int / iris / bitstream/handle / 10665 / 43360/9241545445_spa. pdf? sequence $=1$.

5. Joly, E. ¿Podemos confiar en la ENDI?. IV Jornadas Nacionales Universidad y Discapacidad. Reconocer la Diferencia para Proteger la Igualdad. Del 5 al 7 de julio de 2006. Buenos Aires: Facultad deDerecho; 2006. [Accessedon: June $\left.2^{\text {nd }}, 2018\right]$. Available at: http: / / www.rumbos.org.ar / podemos-confiar-en-la-endi.

6. Agencia Nacional de Discapacidad. Certificado Único de Discapacidad. [Accessed on: June 2nd, 2018]. Available at: https: / / www.argentina.gob.ar/ como-obtener-elcertificado-unico-de-discapacidad-cud.

7. INDEC. Censo Nacional de Población, Hogares y Viviendas 2010. Resultasos de la consulta: Cuadros (5). Buenos Aires, Argentina, 2011. [Accessed on: June $\left.2^{\text {nd }}, 2018\right]$. Available at: https://www.indec.gob.ar/ censos_total_pais.asp?id_tema_1=2\&id_tema_2=41\&id_ tema_3 $=135 \& \mathrm{t}=3 \& \mathrm{~s}=2 \& \mathrm{c}=2010$.

8. Pantano L, Rodríguez Gauna MC. La población con dificultad de largo plazo en la Ciudad Autónoma de
Buenos Aires (Informe 1). Encuesta Anual de Hogares 2011. Buenos Aires: Dirección General de Estadísticas y Censo; 2013. Available at: https://www.estadisticaciudad.gob. ar/eyc/wp-content/uploads/2015/04/2011_poblacion_ con_dificultad_largo_plazo.pdf.

9. Moya G. Derechos de los pacientes con enfermedades que se asocien con discapacidad: marco legal actual. Arch Argent Pediatr. 2016; 114(4):355-60.

10. 10. INDEC ECMI. Censo 2001 - Encuesta Nacional Complementaria de Personas con Discapacidad. [Accessed on:October $6^{\text {th }}$, 2018]. Available at: http:/ / www.indec.gov. ar/micro_sitios/webcenso/ENDI_NUEVA/ampliada_ lista_total.asp?Cap $=13 \&$ Apertu $=0$.

11. Pantano L, Nuñez B, Arenaza A. ¿Qué Necesitan Las Familias de Personas Con Discapacidad? Investigación, reflexiones y propuestas. Buenos Aires: Lugar Editorial; 2012.

12. Ley 26682. Marco Regulatorio de Medicina Prepaga. Buenos Aires, Argentina, 16 de mayo de 2011. [Accessed on: June $1^{\text {st }}$ 2018]. Available at: http://fepra.org.ar/feprav3/ documentos/normas_ejercicio_pais/Ley-de-medicinaprepaga_26682.pdf.

13. Superintendencia de Servicios de Salud. Ministerio de Salud. Programa Médico Obligatorio (PMO). Resolución 201/2002. [Accessed on: June $2^{\text {nd }}, 2018$ ]. Available at: https: / / www.sssalud.gob.ar/pmo/res_s_02_201.pdf.

14. INDEC. Censo Nacional de Población, Hogares y Viviendas 2010. Población Con Dificultad o Limitación Permanente. Octubre de 2014. [Accessed on: June 2 ${ }^{\text {nd }}, 2018$ ]. Available at: https: / / www.indec.gov.ar/ftp/cuadros/sociedad / PDLP_10_14.pdf.

15. Yeargin-Allsopp M, Rice C, Karapurkar T, Doernberg N, et al. Prevalence of Autism in a US Metropolitan Area. JAMA. 2003; 289(1):49-55.

16. BroscoJ, Mattingly M,Sanders L. Impact of Specific Medical Interventions on Reducing the Prevalence of Mental Retardation. Arch PediatrAdolesc Med. 2006; 160(3):302-9. 